\title{
Investigating Adaptation Strategies Developed by Potato Farmers to Cope with Climate Change Impacts in Egypt
}

\author{
Ahmed Harb Rabia $^{1 *}$, Assem A. A. Mohamed ${ }^{2}$, Emad Fawzy Abdelaty ${ }^{1}$, \\ Sara Fekry Shahin ${ }^{3}$, Dalia M. M. Yacout ${ }^{4}$
}

\begin{abstract}
Egypt is one of the top 20 producers of potato worldwide and the first largest producer and exporter of potatoes in Africa in 2019. The aim of this study was to evaluate the adaptation strategies that have been developed by potato farmers in Egypt to cope with climate change impacts. This was achieved by a) Identifying influences of local climate changes, b) Conduct an economic analysis of potato cultivation in the study area, c) Recognizing the influences of farm management practices on potato cultivation stages through consultation, questionnaires, and interviewing local farmers and producers. Results revealed that climate variability had major impacts on potato production in Egypt during the last 15 years. Nowadays, December and January can be considered hazardous months for potato plants, as the plants cannot tolerate the low temperature during these two months. In order to minimize climate change impacts on potato production in Egypt, the following adaptation practices were developed by farmers. To avoid the impacts of high temperatures, farmers should prevent irrigation during the daytime till sunset and irrigate during the night. In case of low temperature, applying irrigation in low quantities with small amounts of ammonia acid through continuous cycles during both day and night will significantly increase the plants' resistance. Also, fencing the farms with tree lines and viaducts will reduce flooding hazards. Finally, adjusting planting dates between the $1^{\text {st }}$ of October until the end of November may help in mitigating the impact of new potato diseases.
\end{abstract}

Keywords: Climate change, Adaptation Strategies, farmer's perception, Potato, Egypt.

\section{INTRODUCTION}

In Egypt, potato accounts for the largest share of the vegetable export market. Potato crop is one of the main vegetable crops in Egypt in terms of production and consumption. The total potato production has reached 5 million ton/year with a market value of 250 million USD. Around $20 \%$ of the entire agriculture land that is used for growing vegetables in Egypt is dedicated to potato production. The percentage of small farmers in Egypt with less than 2 hectares is more than $80 \%$ percent of the landholding; most of this land is in the Nile Delta and Valley (FAOSTAT, 2018). Potato production in Egypt has grown steadily during the last decade with increasing growth in both the cultivated area and yield. Potato is produced in 25 of Egypt's 27 Governorates. However, $65 \%$ of its production occurred in governorates of the Nile Delta, concentrated in areas of suitable soils (El-Hady and Abdelaty) alongside various channels of the Nile delta. The total cultivated area in 2019 was 171 thousand hectares which produced 5.2 million tons, while average potato yield was about 30.3 ton/hectare (FAO, 2015). Furthermore, rereading the local potato prices showed that in 2000 the price reached around $122 \mathrm{USD} /$ ton and later increased to 190 USD/ton in 2013 with an annual average of 156 USD/ton during 2000- 2013. In the meanwhile, in 2000 the international price of potato was around 175 USD/ton and increased in 2013 to be 479 USD/ton with an annual average of 311 USD/ton during 2000- 2013 (FAO, 2015). With the purpose of improving the productivity and quality of potato, several characteristics of the production chain shall be considered in a cohesive means. Theses aspects include choosing of proper planting dates, quality seeds, forecasting of pests and diseases, irrigation management, fertilization techniques, as well as the soil quality.

Several potato simulation models were used to study the possible impacts of climate change at global, regional, and local scales. The potato models future projections showed that the impacts will vary spatially. For example, current production regions may move toward cooler regions (Hijmans, 2003; Supit et al., 2012; Tubiello et al., 2002). In addition, potato yields would decrease by the end of the century (Raymundo et

DOI: 10.21608/asejaiqjsae.2021.205325

${ }^{1}$ Department of Natural Resources and Agricultural Engineering,

Faculty of Agriculture, Damanhour University, Damanhour, Egypt.

${ }^{2}$ Central Laboratory for Agricultural Climate (CLAC),

Agricultural Research Centre, Giza, Egypt.

${ }^{3}$ Center for Biotechnology and Genomics, Texas Tech University,

Lubbock, TX, USA

${ }^{4}$ Swedish University of Agricultural Sciences, Uppsala, Sweden.

*Corresponding author: Tel.: (+2) 01550088422 ,

E-mail: ahmedrabia@agr.dmu.edu.eg

Received October 05, 2021, Accepted, November09, 2021. 
al., 2014). Several studies showed that the Nile Delta is one of the vulnerable areas affected by expanding urbanization and climate change impacts. However, few studies addressed this problem in Egypt (Rabia et al., 2018). Consequently, there is a growing need to investigate the impacts of climate change on potato cultivation and to recognize the principal factors that may affect the farming processes and finally to endorse adaptation and conservation strategies suitable for different local conditions. Therefore, the aim of the study was to evaluate the possible adaptation strategies developed by potato farmers to cope with climate change impacts in North Egypt.

\section{MATERIAL AND METHODS}

\section{Study area}

Most of the potato production in Egypt is located in the Nile Delta and Middle Egypt. Exported potato production in Egypt is centered in the governorates of Garbiya, Menofya, and El-Behera. Where yield range between 32, 27, and 28.9 tons/hectare (FAO, 1997). ElBehera governorate is the leading producer and exporter of potato not only in the Nile Delta but in Egypt as well. Total cultivation area of potato in El-Behera reached 43 thousand hectare with an annual production of 1.2 million tons (Center of Agriculture Research, 2003).
Therefore, El-Behera governorate was chosen as a study area. El-Behera is one of the largest governorates in Egypt, located in the west of the Nile delta. Its boundary to the south is El-Giza governorate, to the west is Alexandria and Matrouh governorates, to the east is Rosetta Nile branch and to the north is the Mediterranean Sea. The governorate has a population of 6.17 million people, around $9826 \mathrm{~km} 2$ of total area, and a population density of 770 people/ $\mathrm{km}^{2}$ (Egypt National Report, 2018). With a cultivated area of around $14.86 \%$ of the total, Egyptian agriculture land, it is the largest agricultural governorate in the country. The winter season is considered the main cultivation season in ELBehera for exported-potato production (FAO, 2006; SIS, 2016).

The study area is located on the two sides of the Alexandria-Cairo desert road in El-Behera Governorate. It starts from Al_Galaa village as a starting point (3419830.17 E, 775858.17 N) until Wadi El-Natrun city as an ending point (3365116.01 E, 248098,73 N) with a length of approximately $146 \mathrm{Km}$. The Western border extended to $15 \mathrm{Km}$ from Desert road and the Eastern border of the study area is Nubaria canal. The total area is approximately 29094 hectares (Figure 1).

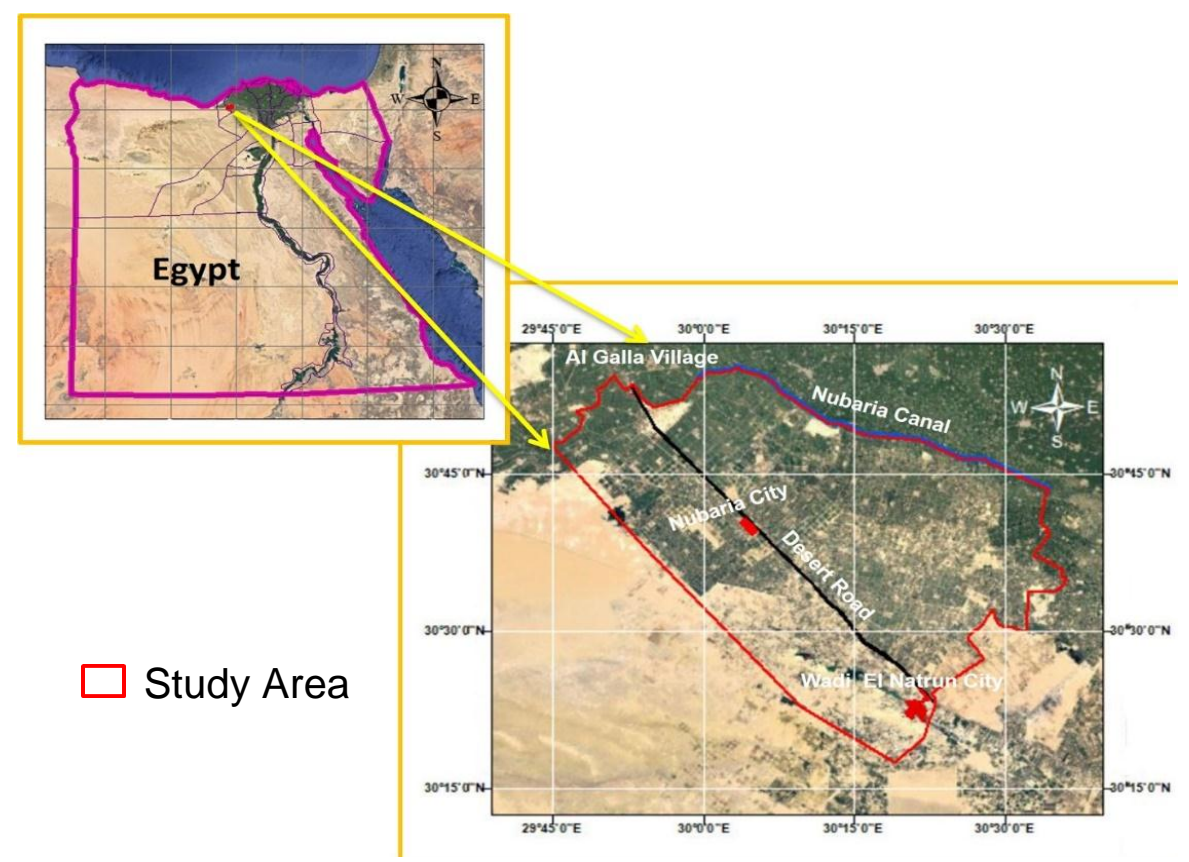

Fig. 1. Representation of the study area 


\section{Geology and soil characteristics}

The surface of the study area is essentially formed of sedimentary rocks and deposits belonging to the late Tertiary and the Quaternary. The Miocene rocks are exposed in the area south and west of the study area, while the recent deposits are scattered all over the area especially along the low-lying parts. Late Tertiary and Quaternary succession in the study area and adjacent areas are briefly discussed by many authors (Abdel Baki, 1983; Attia, 1975; EI-Fayumy, 1964; Omara and Sanad, 1975; Shata, 1955, 1962; Shata and El-Fayoumy, 1969; Shata et al., 1970; Shieded, 1989). According to Abdel-Kader et al. (Abdel-Kader et al., 1998), the main soil orders in the study area are Aridisols and entisols.

\section{Local Climate analysis}

Agroclimatic data was collected from Tahrir Station, which lies at latitude 30.39 and longitude 30.42 at altitude $16 \mathrm{~m}$ above sea level. This data show that the study area is very arid with aridity index (0.02) and lies in an agroclimatic region named hyper-arid, mild winter, warm summer (Ali et al., 2018). The historical data (2004-2019) indicated that the mean annual temperature of $21.2^{\circ} \mathrm{C}$ and mean monthly temperature ranging from $13.7^{\circ} \mathrm{C}$ in January to $27.8^{\circ} \mathrm{C}$ in August. The highest temperatures recorded over the last 10 years were $34.50^{\circ} \mathrm{C}$ in July and the lowest was $7.80^{\circ} \mathrm{C}$ in January. The mean monthly relative humidity ranged from $52 \%$ in May and $70 \%$ in November and December. The minimum relative humidity (about 30\%) occurs at about 2.00 p.m. The speed of wind ranges between $11 \mathrm{Km} / \mathrm{hr}$ in December and January to 20 $\mathrm{Km} / \mathrm{hr}$ in May and June. Finally, the general winds are those moving from the North, Northwest and Northeast direction.

When investigating climate change impacts on an agricultural product, different climate analysis should be considered (Knox and Wade, 2012). In this study, a general analysis of climate at the local level and a projection for the future (up to 2030) was carried out. Historical climate data for the study area was obtained from the Central Laboratory for Agricultural Climate (CLAC- ARC) of Egypt. Climatic data collection included (Temperature, precipitation, wind, solar radiation ...etc.). The baseline of 2000 was produced using the potato production statistics, land and water resources, diseases outbreaks and population statistics. Statistics of potato production during the last 16 years (from 2004 to 2019) were obtained from Egyptian Ministry of Agriculture and Land Reclamation (MALR).

\section{Economic analysis}

The research applied both descriptive and quantitative statistics such as simple linear regression.
The current study is based on annual data for the period (2004-2019) obtained from various sources, including Ministry of Agriculture and Land Reclamation (MALR), the Central Agency for Public Mobilization and Statistics (CAPMAS), the United Nations Food and Agriculture Organization statistical database, the United Nations Commodity Trade Statistics Database and the World Bank.

\section{Survey and Fieldwork}

A field survey for 20 large farms (>200 hectare each) at Nubaria zone were selected to conduct the field survey for data collection. The selected farms represent the leader potato producers in the area. These farms are producing approximately $30 \%$ of the total potato production devoted to exportation. The survey was conducted to attain the leader producers' individual strategies and adaptation actions to climate change. Leader producers were interviewed; all the production stages and the evolution in time of their systems were studied to identify the key-practices that brought to a successful productive result for potato cultivation in terms of environmental and socio-economic sustainability.

\section{RESULTS AND DISCUSSION}

Data of the climate analysis at the local level and forecasting for the future (up to 2030) showed that the year 2010 had the highest maximum temperature average with $30.64{ }^{\circ} \mathrm{C}$ and the year 2013 had the lowest maximum temperature average with $25.18{ }^{\circ} \mathrm{C}$. The forecast of maximum temperature averages up to the year 2030 (Figure 2) is suggesting that the maximum temperature average is declining to reach approximately $27.5{ }^{\circ} \mathrm{C}$. These results are based on the available data and may not correctly reflect the accurate sequence of temperatures during a longer period of previous years (IPCC, 2018).

To study the minimum temperature, both the records of December and January for each year in addition to the yearly minimum temperature average were presented and analyzed. This is due to the fact that in Egypt the days with the lowest minimum temperature usually happen during December and January. Therefore, both of the months are hazardous to potato plantations because the plants during these months are still in the first stage of the planting season. The forecast is suggesting that the minimum temperature average is increasing for both January and December by the year 2030 (Figure3). Hijmans (2003), described in his forecast that an increase of 1 to $1.4{ }^{\circ} \mathrm{C}$ in the temperature will reduce the potential global potato yield by $9 \%$ to $18 \%$ with adaptation and by $18 \%$ to $32 \%$ without adaptation. 


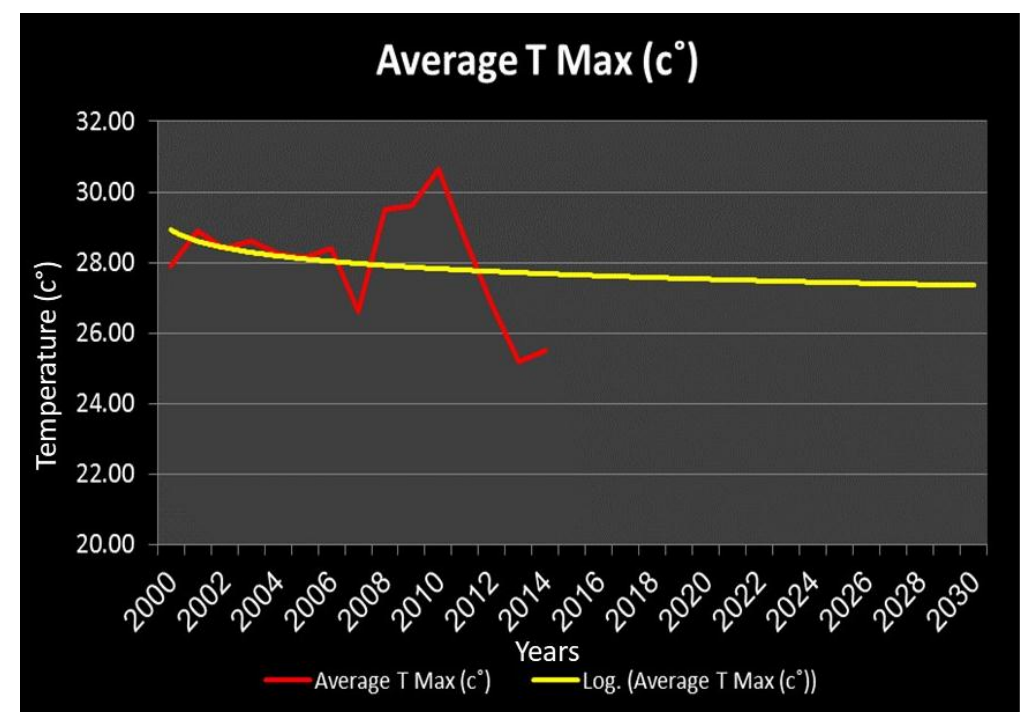

Fig. 2. Average yearly maximum temperature $\left({ }^{\circ} \mathrm{C}\right)(\mathbf{2 0 0 0 - 2 0 1 4})$ and forecasting for 2030

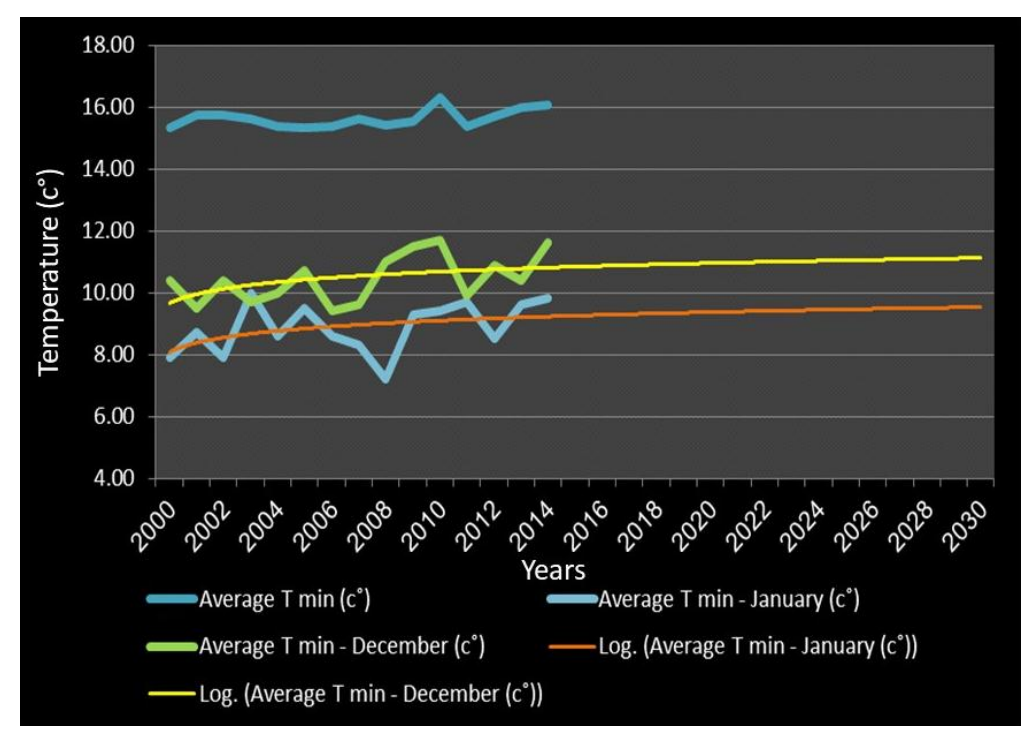

Fig. 3. Average yearly minimum temperature $\left({ }^{\circ} \mathrm{C}\right)$, Average temperature of January and December (20002014) and forecasting for 2030

In addition, based on the survey with potato growers, it was found that the most influential months in terms of wind speed are the months of March and April. Therefore, the wind speed was analyzed only for both months. It is clear, from the data in Figure (4), that the mean wind speed has increased in the last four years (2010-2014). Therefore, the forecast is suggesting that the mean wind speed will increase exponentially in the next fifteen years. This introduces a new limiting factor for potato cultivation, as the increase of wind speed in these months will lead to significant crop damages. In terms of rainfall amounts, the data analysis revealed that there is a significant increase in the total amount of rainfall yearly (Figure 5). However, by screening the years with very high values of total rainfall amount it was found that the increase is due to significant extreme events (rain showers) that happened in those years (2006, 2009, 2012). These extreme events have led to damages of crops and in some unfortunate cases to deaths (Alam et al., 2017). Finally, more in-depth analysis of climate data needs to be done in order to include more variables and extend the analysis to a longer time period. 


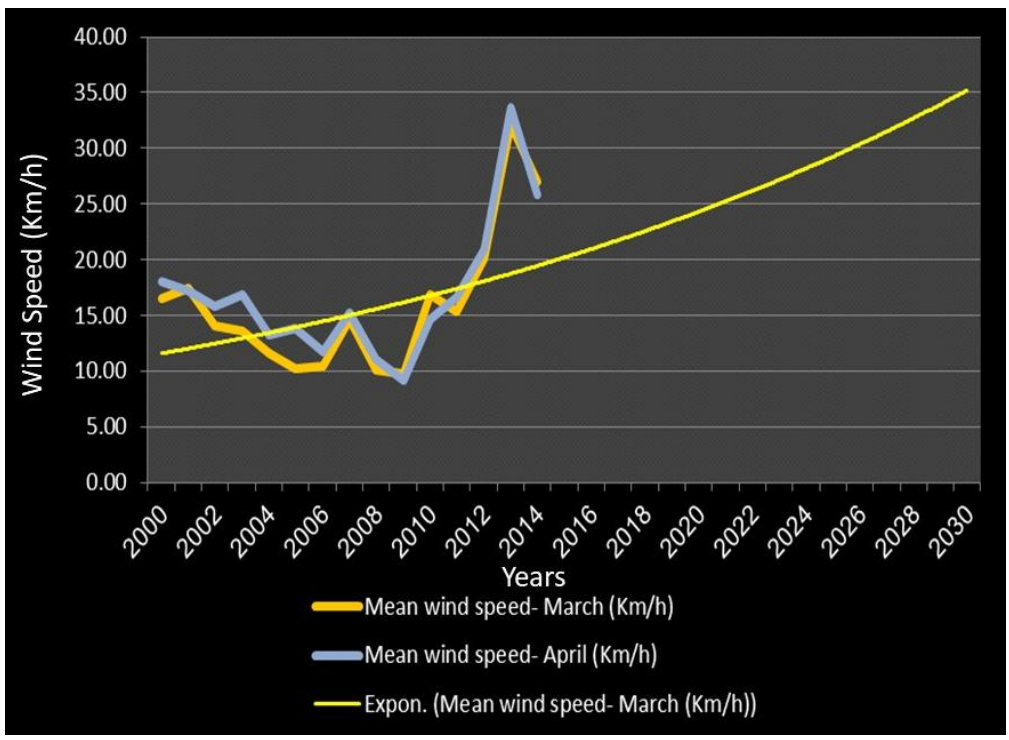

Fig. 4. Mean wend speed $(\mathrm{Km} / \mathrm{h})$ of March and April (2000-2014) and forecasting for 2030

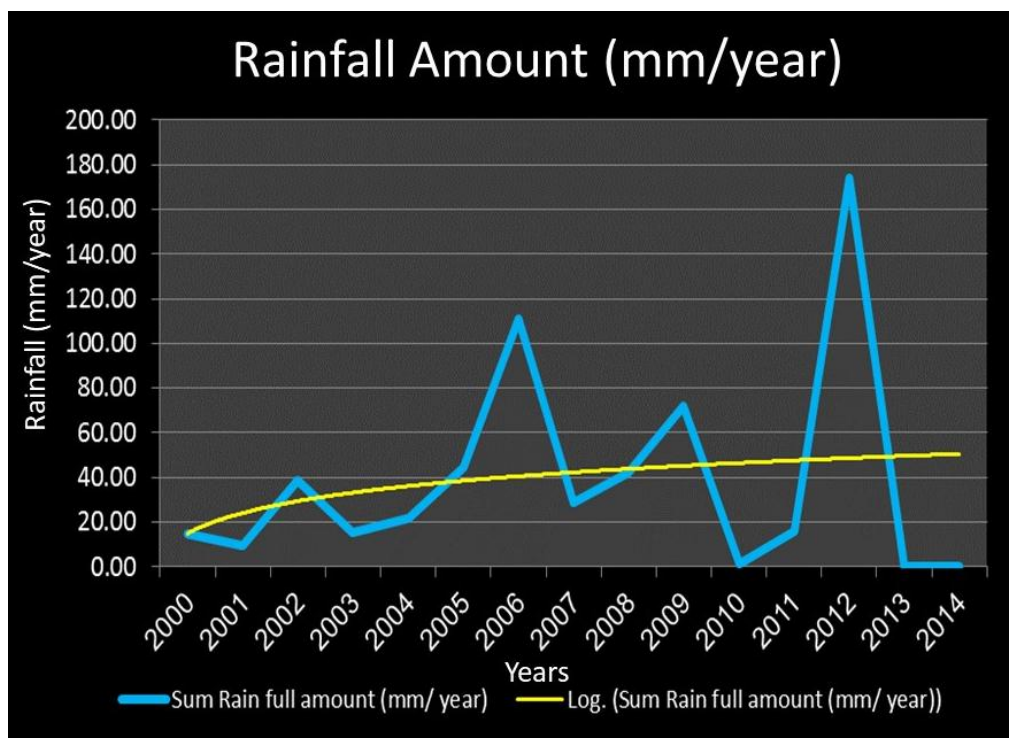

Fig. 5. Total rainfall amount ( $\mathrm{mm} / \mathrm{year})$ for the years $(2000-2014)$ and forecasting for 2030

Economic analysis of Potato cultivation

Evolution of cultivated potato area in El-Behera Governorate

Total cultivated area of potato during 2004- 2019 in EL-Behera Governorate illustrated in Figure (6). The average cultivated area was 41 thousand hectares, while the cultivated area of potato reached its maximum, 51.3 thousand hectares, in 2012 and minimum, 26.8 thousand hectares, in 2006. Equation (1) in Table (1) shows that the total area of potato cultivation in El-Behera increased by an annual statistical significant rate reaching 3.96 thousand hectares during the period of 2004- 2019. 


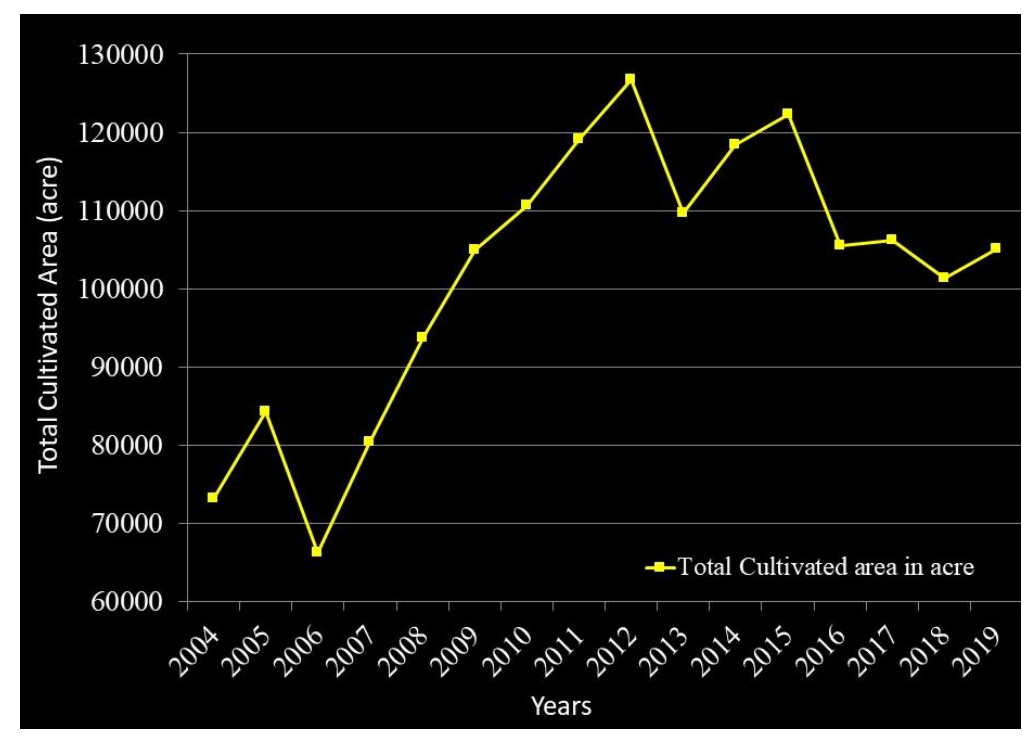

Fig. 6. Potato total cultivated area in El-Behera during the period of 2004- 2019

Table 1. General trend equations of potato total area and total production in El-Behera Governorate during the period of 2004- 2019

\begin{tabular}{clcccc}
\hline Items & \multicolumn{1}{c}{ Equation } & $\mathbf{R}^{2}$ & $\mathbf{F}$ & $\mathbf{T}$ & no \\
\hline Potato total area (hectare) & $\hat{\mathrm{Y}}_{\mathrm{i}}=45851.9+9796.9 \mathrm{X}_{\mathrm{i}}$ & 0.84 & 80.4 & 8.96 & $\begin{array}{c}\text { Equation } \\
1\end{array}$ \\
& & & & & \\
Potato total production (tonns) & $\hat{\mathrm{Y}}_{\mathrm{i}}=406197.2+108575.7 \mathrm{X}_{\mathrm{i}}$ & 0.85 & 87 & 9.34 & $\begin{array}{c}\text { Equation } \\
2\end{array}$ \\
\hline
\end{tabular}

Where:

$\hat{Y}_{i}=$ the estimated value for the dependent variable in the year i., $X_{i}=$ reflect time variable in the year i., $i=1,2,3 \ldots \ldots 16, R^{2}=$ Determination coefficient. F= F- Test, a statistical test in which the test statistic is based on the F-distribution under the null hypothesis. $\mathrm{T}=\mathrm{T}$-Test, test on individual regression coefficients

\section{Evolution of total potato production and yield in El-} Behera Governorate

As shown in Figure (7) the average production of potato during the period 2004- 2019 was 1.1 million tones, minimum potatoes total production was 683.4 thousand tons in 2006, and reached the maximum production of 1439.5 thousand tons in 2015. Equation (2) in Table (1) shows that the total production of potato in El-Behera had increased by an annual statistically significant rate reached 108.5 thousand tons during the period of 2004- 2019, which means that the annual production increased, this is basically attributed to the increase in cultivated area. In Addition, Figure (8) shows that potato yield was about 25.37 ton/ hectare in 2004. In fact, potato yield of El-Behera fluctuated up and down during the study period, reached its maximum 29 ton/ hectare in 2015. 


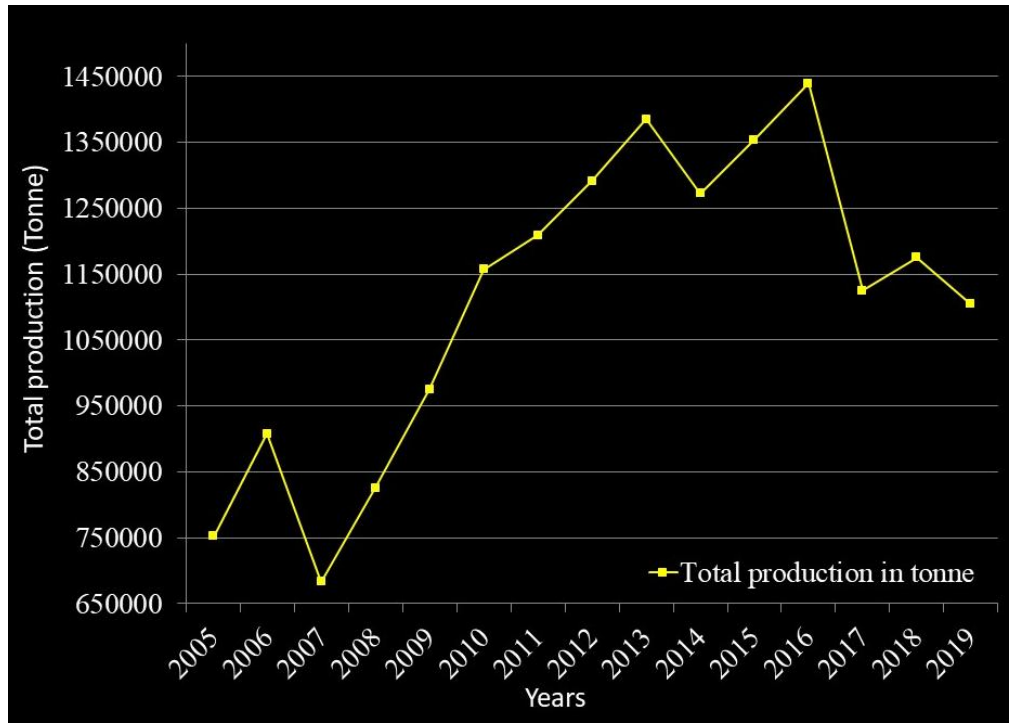

Fig. 7. Total production area of potatoes in El-Behera during the period of 2004- 2019

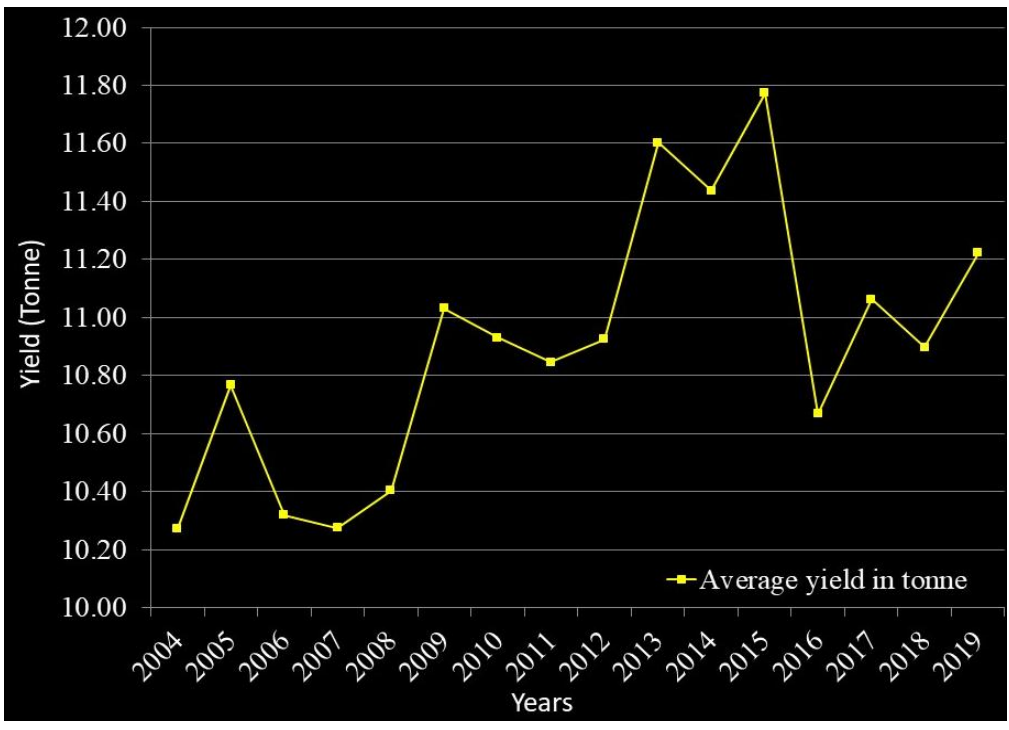

Fig. 8: Potatoes yield in El-Behera during the period of 2004- 2019

\section{Main findings of the field survey}

Summary results based on approaching the leaders of potato production through field visits, interviews, and surveys are as follows:

\section{Farms location and general information}

The main farms of producers for potato production in Al-El-Behera governorate were visited. The farms were mainly located at Nubaria and Wadi El-Natrun areas. Total area of Farm's varied between 200 and 4000 hectares. The main reason for potato production by the farms is for exportation to Europe, next for local food processing and consumption in the local market. Potato production duration varies between $100-140$ days from planting date. Used seeds for planting are usually imported seeds from Japan or Holland; some farms produce their own seeds. All farms used conventional potato farming not organic. They agreed that organic farming is not suitable with the supplied irrigation water which contains high levels of minerals. Annual potato production ranges between $25-61$ ton/hectare, with an approximate cost of LE 898 /hectare. 


\section{Potato varieties}

All potato growers agreed during the survey visits that changes in the potato varieties planted in the previous 15 years were not related to climatic changes or their effects. But these differences are based on market demand and what is needed for the export market. For example, the varieties cultivated for export to the German market is different from varieties cultivated for the English or French export markets, based on the desires of the consumer. While in the case of the domestic market, varieties such as "Sponta", "Cara" and "Mondial" have been cultivated for a long time as a result of continued desirability of increased demand and the Egyptian consumers (Shaheen et al., 2016). So, the final conclusion was that the choice of varieties of potato is mainly based on the request of the export market or the domestic market, regardless of these varieties resistant to the conditions of climate change or not.

\section{Planting dates}

The results of the field visits to potato growers showed that planting dates and agricultural processes have differed in the past 15 years due to many factors. One of the most important factors is the change in the local climate and, in particular, changes in temperature and air humidity. Although not all the farmers agreed on a specific date for potato planting, they all agreed that the optimum period for potato planting in North Egypt is between the $1^{\text {st }}$ of October to the end of November. On the other hand, all potato growers that have been interviewed approved that the planting dates have been delayed in general by two to three weeks as a result of the temperature rise in September and October, which adversely affect the germination process. Additionally, they explained that very low temperatures during December and January may cause negative influence largely on the productivity of the potato crop if happened after the end of the vegetative stage. Where the plant after this stage will not be able to recover or resist the strong weather conditions. Interviewed farmers have agreed that the method used in case of high-temperature events, as well as very low temperature events, are by increasing the irrigation amount to help the plant to resist these sever conditions.

\section{Potato diseases}

As for the diseases that infect potato crop, farmers have suggested that there have been new diseases that infected potato crop in the last 15 years as an indirect effect of climate change. The results of the field visits revealed a rising in the incidence of fungal diseases, such as "Early Blight" and "late Blight" in the previous 15 years. This is a result of the increase in the air humidity during the potato growing season, which led to increased incidents of fog in the potato growing areas.
Results also showed a high incidence of insect infestation in the potato crop and the emergence of new insect diseases that did not infect the potato crop before 2000 (such as Tuta absoluta and aphid).

\section{Vulnerability assessment}

From the above results and in agreement with previous studies we conclude that the cultivation of potato crop is nowadays facing many risks associated directly or indirectly with climate changes and their effects (Abdrabbo et al., 2010; Daccache et al., 2011; Haverkort et al., 2013; Hijmans, 2003; Knox and Wade, 2012). These risks vary throughout the planting season, starting with changing planting dates due to temperature changes, resulting in exposure of potato plants to additional risks of fungal and insect diseases (Rabia et al., 2016). The increase in the chances of severe rainfall events during the winter season led, in some years, to the loss of the entire potato crop in some farms. In the spring period, the plant is exposed to strong wind, which often causes a large proportion of the crop to be lost due to vegetation damage. From the above, the significant negative impact of climate change on the potato crop is evident in the study area. This requires researchers and decision-makers to take many steps to mitigate these effects and to reduce the losses incurred by farmers.

\section{Local adaptation practices}

Based on actual practices and field experience by leaders of potato production a number of adaptation strategies can be implemented in order to reduce climate change impacts on potato production during the different production stages:

\section{a) Irrigation}

Irrigation is one of the most important factors affecting potato production. Previous studies (Abdrabbo et al., 2010; Daccache et al., 2011) emphasized the influences of climate change on potato production in humid and dry conditions, respectively. Abdrabbo et al. (2010) studied the sensitivity of potato yield to climate change in Egypt and reported that a potential 11 to $13 \%$ decrease in potato yield due to climate change. In order to minimize this potential decrease, it is recommended to prevent irrigation during daytime until the sun set in case of high temperature, then apply irrigation during night only. In case of low temperature, irrigation should be applied by low quantities with small amounts of ammonia acid through continues cycles during both day and night.

\section{b) Flooding}

Despite flooding is one of the extreme events that rarely occur in this study area, it took place in 2015 and caused large losses to potato production. 
Caution recommended practices are fencing the farm with tree lines and viaducts.

\section{c) Changing planting dates}

Recently, new potato diseases emerged due to increase in air humidity in the fields during the first stages of planting. These types of disease can be mitigated by adjusting planting timing to be from the $1^{\text {st }}$ of October until the end of November.

\section{CONCLUSION}

The study focused on assessing the potential adaptation strategies for coping with climate change impacts on potato in North Egypt. Local climate analysis for the last 15 years (from 2004 to 2015) was done in addition to projection of future climate up to 2030. Preferable farm management practices and an assessment for the vulnerability of potato to climate change was identified by field survey for 20 large farms (>200 hectares). Data analysis and survey indicated that potato planting should be avoided during December and January. As the plants will be in their first stage and will not be able to tolerate the low temperature. It was found that wind is an important factor impacting potato production, especially during the upcoming years as the forecast indicated that wind speed will increase. During the last 15 years, extreme weather events (rain showers) in 2006, 2009 and 2012 had significant damage to the production. Identified adaptation strategies to minimize climate change impacts were introduced. In case of high temperature events, preventing irrigation during daytime and applying it during the night to avoid impacts of high temperatures. In case of low temperature, irrigation should be applied by low quantities with small amounts of ammonia acid during both day and night. In order to avoid new potato diseases, planting time should be between $1^{\text {st }}$ of October till end of November. Finally, it is recommended to conduct a more in-depth analysis for climate data in order to include more variables and extend the analysis to a longer time period.

\section{ACKNOWLEDGEMENTS}

This work was part of the research project titled "Towards Sustainable Potato Production under Climate Change Conditions" funded by the Alexandria Research Center for Adaptation to Climate Change (ARCA) and IDRC Canada. Also, the authors appreciate the technical and logistic support from the SPACE Center (Sustainable Production and Adaptation to Climate Change Effects center) at Faculty of Agriculture, Damanhour University during the production of this publication.

\section{REFERENCES}

Abdel Baki, A.A. 1983. Hydrological and Hydrogeochemical Studies on the Area West of Rosetta Branch and South of El-Nasr Canal: Ph.D. Thesis, Fac. Sci., Ain Shams Univ., Cairo, Egypt, 122p.

AbdEl-Hady, A.M and E.F. Abdelaty. 2019. GIS Comprehensive Analytical Approach for Soil Use by Linking Crop Soil Suitability to Soil Management and Reclamation. Alex. Sci. Exch. J. 40: 60-82.

Abdel-Kader, M.M., B.R. Ismail, M.M. Diab and E.A. Hassan. 1998. Preliminary evaluation of some soilborne fungi parasitiz-ing Orobanche crenata in greenhouse. In "6th Mediteranean symposium. EWRS", pp. 127-132, Montpellier, France.

Abdrabbo, M.A.A., A.A. Khalil, M.K.K. Hassanien and A.F. Abou-Hadid. 2010. Sensitivity of Potato Yield to Climate Change. Journal of Applied Sciences Research .6:751-755.

Alam, H., J.Z. Khattak, S.B. Ppoyil, S.S. Kurup and T. Ksiksi. 2017. Landscaping with native plants in the UAE: A review. Emirates Journal of Food and Agriculture .29:729741.

Ali, H.G., D.M. Yacout, S.F. Shaheen and A.H. Rabia. 2018. Assessment of Climate Change Impacts on Barley Production in Rain-Fed Areas in Northern Egypt. In "2nd International Conference of Biotechnology and Environment (ICBE) ".

Attia, S.H. 1975. Pedology and Soil Genesis of the Quaternary Deposits in the Region West of the Nile Delta, North and East of Wadi El-Natrun: Ph.D. Thesis, Fac. Sci., Ain Shams Univ., Cairo, Egypt, 258p.

Center of Agriculture Research. 2003. Ministry of agriculture and land reclamation economic affairs sector.

Daccache, A., E.K. Weatherhead, M.A. Stalham and J.W. Knox. 2011. Impacts of climate change on irrigated potato production in a humid climate. Agr. Forest Meteorol. 151:1641-1653

Egypt National Report .2018. Addis Ababa Declaration on Population and Development in Africa beyond 2014 (AADPD +5).

EI-Fayumy, I.F. 1964. Geology of Groundwater Supplies in Wadi El-Natrun Area: M.Sc. Thesis, Fac. Sci., Cairo Univ., Egypt, 109p.

FAO .2006. Food and Agriculture Organization of the United Nations, Rome. .

FAO. 1997. "Plant nematode problems and their control in the Near East region: proceedings of the Expert Consultation on Plant Nematode Problems and their Control in the Near East Region." Food and Agriculture Organization of the United Nations, Rome, Karachi, Pakistan.

FAO. 2015. "Food and Agriculture Organization of the United Nations, Rome, 2015. FAO Statistical Pocketbook (http://www.fao.org/3/a-i4691e.pdf). "

FAOSTAT .2018. The database of the United Nations Food and Agriculture Organization statistical database. Retrieved from http://www.fapstat.org 
Haverkort, A.J., A.C. Franke, F.A. Engelbrecht and J.M. Steyn .2013. Climate Change and Potato Production in Contrasting South African Agro-ecosystems: Effects on Land and Water Use Efficiencies. Potato Research. 56:3150 .

Hijmans, R.J. 2003. The Effect of Climate Change on Global Potato Production. . Amer J of Potato Res. 80:271-280.

IPCC .2018. "Global Warming of $1.5^{\circ} \mathrm{C}$. An IPCC Special Report on the impacts of global warming of $1.5^{\circ} \mathrm{C}$ above pre-industrial levels and related global greenhouse gas emission pathways, in the context of strengthening the global response to the threat of climate change, sustainable development, and efforts to eradicate poverty [V. MassonDelmotte, P. Zhai, H. O. Pörtner, D. Roberts, J. Skea, P.R. Shukla, A. Pirani, W. Moufouma-Okia, C. Péan, R. Pidcock, S. Connors, J. B. R. Matthews, Y. Chen, X. Zhou, M. I. Gomis, E. Lonnoy, T. Maycock, M. Tignor, T. Waterfield (eds.)].".

Knox, J.W and S. Wade. 2012. Assessing climate risks to UK agriculture. Nature Climate Change. 2-378.

Omara, S.M and S. Sanad. 1975. Rock Stratigraphy and Structural Features of the Area Between Wadi El-Natrun and Moghra Depression, Western Desert Egypt: Geol. J., BL.6, Hanover, pp.45-73.

Rabia, A.H., D.M. Yacout and S.F. Shaheen. 2016. Towards Sustainable Potato Production under Climate Change Conditions: a community-based adaptation approach. In " The 43rd, Annual Conference of the Association of Egyptian-American Scholars (AEAS), Zewail City of Science and Technology (ZC), " Giza, Egypt.

Rabia, A.H., D.M.M. Yacout, S.F. Shahin, A.A.A. Mohamed and E.F. Abdelaty. 2018. Towards Sustainable Production of Potato under Climate Change Conditions. Current Applied Science and Technology .18:200-207.

Raymundo, R., S. Asseng, D. Cammarano and R. Quiroz .2014. Potato, sweet potato, and yam models for climate change: A review. Field Crops Research.166:173-185.
Shaheen, S.F., D.M. Yacout and A.H. Rabia. 2016. Comparison between Potato (Solanum tuberosum L.) Cultivars and Abiotic stress genes. In "The international conference "EnviroInfo 2016 - Environmental Informatics - Stability, Continuity, Innovation: Current trends and future perspectives based on 30 years of history", HTW University, Berlin, Germany.

Shata, A.A and I.F. El-Fayoumy. 1969. Remarks on the Hydrogeology of the Nile Delta: Sympos. Hydrology of Delta, UNESCO, Vol.2, pp. 385-396.

Shata, A.A. 1955. An Introductory Note on the Geology of the Northern Portion of the Western Desert of Egypt: Bull. Inst. Desert, Egypt, T.5, No.3, pp. 96-106.

Shata, A.A. 1962. Geology, In Preliminary Reports on Geology, Hydrology and Groundwater Hydrogeology of Wadi El-Natrun and Adjacent Areas. Part 1; Cairo, U.A.R., Desert Institute, the General Desert Development Organization, 39p.

Shata, A.A., E.-F.I. F and M. Tamer. 1970. Geomorphology, Geology, Hydrogeology and Soil of Wadi El-NatrunMaryut Agriculture Project: Int. Rep., Desert instit., 19p.

Shieded, A.G. 1989. Geological and Hydrogeological Studies of El-Sadat and its Vicinities: M.Sc. Thesis, Fac. Sci, ElMenoufia Univ., Shibin El-Kom, Egypt, 157p.

SIS .2016. State Information System www.sis.gov.eg

Supit, I., C. Van Diepen, A. De Wit, J. Wolf, P. Kabat, B. Baruth and F. Ludwig. 2012. Assessing climate change effects on European crop yields using the Crop Growth Monitoring System and a weather generator. Agricultural and Forest Meteorology .164:96-111.

Tubiello, F., C. Rosenzweig, R. Goldberg, S. Jagtap and J. Jones. 2002. Effects of climate change on US crop production: simulation results using two different GCM scenarios. Part I: wheat, potato, maize, and citrus. Climate research. 20:259-270. 


\section{الملخص العربي}

\section{دراسة استراتيجيات التكيف التي وضعها مزارعو البطاطس لمواجهة تأثثرات تغير المناخ في مصر}

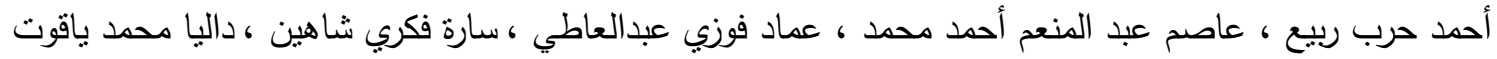

للنباتات تحمل درجات الحرارة المنخفضة خلال هذين الثهرين. من أجل نقليل تأثيرات تغير المناخ على إنتاج البطاطس في مصر، طور المزارعون ممارسات التكيف

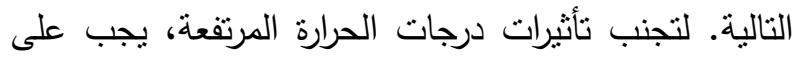

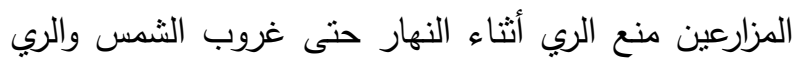

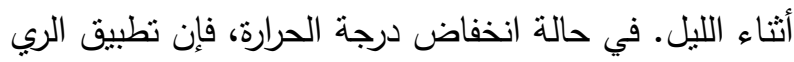
بكميات منخفضة مع كميات صغيرة من حمض الأمونيا من

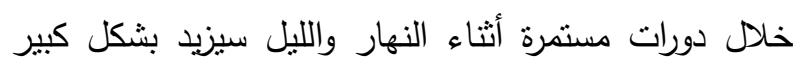
من مقاومة النباتات. كما أن تسييج المزارع بخطوط الأثنجار

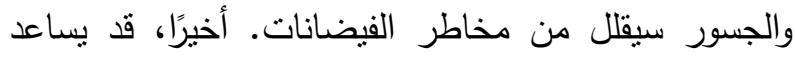
تعديل مواعيد الزراعة بين الأول من أكتوبر وحتى نهاية

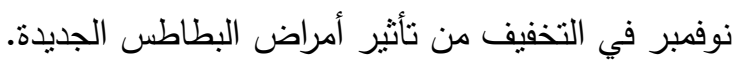
الكلمات المفتاحية: تغير المناخ، استراتيجيات التكيف، تصور المزارعين، البطاطس، مصر
تعد مصر واحدة من أكبر ·r منتجًا للبطاطس في جميع

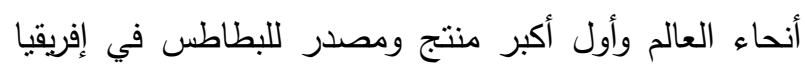

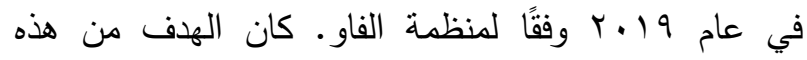
الدراسة هو نقييم إستراتيجيات التكيف التي طورها مزارعو

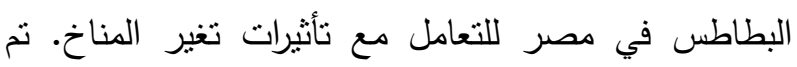
تحقيق ذلك من خلال أ) تحديد تأثيرات التغيرات المناخية

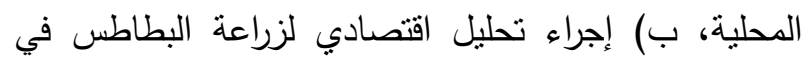

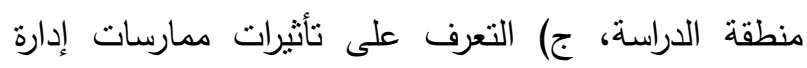
المزرعة على مراحل زراعة البطاطس من خلال التثاور والاستيبانات وإجراء مقابلات مع المزارعين المحليين

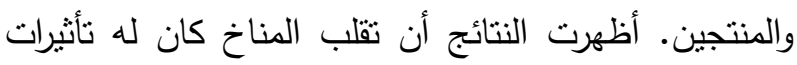
كبيرة على إنتاج البطاطس في مصر خلال الخمسة عشر

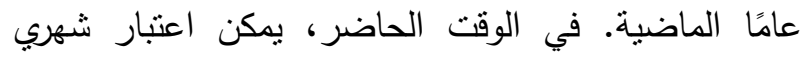
ديسمبر ويناير أنشهر خطرة لنباتات البطاطس، حيث لا يمكن البرفي 